2015-08

\title{
Accumulation of silver by Fucus spp. (Phaeophyceae) and its toxicity to
}

Fucus ceranoides under different salinity regimes.

Ramesh, K

http://hdl.handle.net/10026.1/3913

10.1007/s10646-015-1495-8

Ecotoxicology

All content in PEARL is protected by copyright law. Author manuscripts are made available in accordance with publisher policies. Please cite only the published version using the details provided on the item record or document. In the absence of an open licence (e.g. Creative Commons), permissions for further reuse of content should be sought from the publisher or author. 


\title{
Accumulation of silver by Fucus spp. (Phaeophyceae) and its toxicity to Fucus ceranoides under different salinity regimes
}

\author{
K. Ramesh ${ }^{1} \cdot$ S. Berry ${ }^{2} \cdot$ M. T. Brown ${ }^{2}$
}

Accepted: 18 May 2015

(C) Springer Science+Business Media New York 2015

\begin{abstract}
Metals constitute an important group of abiotic stressors that elicit stress responses in marine algae that include the production of reactive oxygen species (ROS). Silver $(\mathrm{Ag})$ is a highly toxic metal to organisms but despite this there are relatively few studies on how it affects marine macroalgae (seaweeds). In a landmark study published in 1977 the first information was provided on the accumulation of Ag in Fucus spp. (Phaeophyceae) from the Looe estuary, located in south-west England, an area with a long history of mining activity. In the present study, the estuary has been re-visited and the patterns of Ag accumulation in two Fucus spp. and sediment re-examined after 35 years. We conclude that $\mathrm{Ag}$ concentrations in sediment and macroalgae from specific sites within the catchment remain high, but more generally sediment concentrations have declined by approximately $65 \%$ and the dissolved, bioavailable fraction by $24 \%$ over this period. In addition, from laboratory studies we provide data on the speciation and toxic effects of Ag under different salinity regimes in the euryhaline brown seaweed, Fucus ceranoides. From these exposure experiments, it was found that with increasing $\mathrm{Ag}$ concentrations growth was inhibited and lipid peroxidation associated with ROS production increased. The magnitude of the toxic effects was greater at a salinity of 10 than 28 psu which reflects the greater bioavailability of the toxic species of $\mathrm{Ag}\left(\mathrm{Ag}^{+}\right.$and $\left.\mathrm{AgCl}^{0}\right)$ at reduced salinities. These findings emphasise the importance of
\end{abstract}

K. Ramesh

kramesh@geomar.de

1 GEOMAR Helmholtz Centre for Ocean Research, 2 Hohenbergstraße, 24105 Kiel, Germany

2 School of Marine Science and Engineering, Plymouth University, Drake Circus, Plymouth, Devon PL4 8AA, UK investigating the effects of metal pollution in conjunction with other, natural, environmental stressors such as salinity.

Keywords Fucus spp. S Silver · Accumulation · Toxicity · Salinity

\section{Introduction}

Metals pose an immediate threat to coastal waters globally, since they are non-biodegradable and readily bio-accumulate, potentially causing a health risk to the resident biota (Esposito et al. 2001; Mamboya 2007). In near-shore waters macroalgae, such as Fucus species, are major primary producers and key ecosystem engineers, providing a habitat for a large diversity of organisms. Thus, any adverse effects to macroalgae would have consequences for higher trophic level species. Exposure to metals (e.g. cadmium, copper, zinc) can inhibit growth, impair photosynthetic performance, inactivate key enzyme systems and induce oxidative damage via the production of reactive oxygen species (ROS) such as singlet oxygen, superoxide ions, hydrogen peroxide and hydroxyl radicals (Pinto et al. 2003; Burzynski and Zurek 2007; Rai et al. 2008). Oxidative stress is due to the imbalance between ROS and an organism's ability to detoxify the reactive intermediates or repair the consequent damage to proteins, lipids and DNA (Halliwell and Gutteridge 1989; Collen and Davison 1999). Algae counter the production of ROS by synthesising low molecular weight antioxidants and inducing the activities of a suite of antioxidative enzymes (Pinto et al. 2003). Marine macroalgae, and especially brown algae (Phaeophyceae), accumulate metals to high concentrations that are attributed to the presence of negatively charged 
polysaccharides and physodes to which they bind (Salgado et al. 2005; Mamboya 2007). For this reason they are especially suitable for studies on metals and are frequently classed as good sentinel organisms of metal pollution in coastal and estuarine environments.

Mining activities in south west England dating back to Roman times, but particularly in the second half of the $19^{\text {th }}$ century, have left legacies of metal contamination in many of the estuaries within the region (Bryan 1984; Rainbow et al. 2011) The consequences of such activities on their ecologies has been well studied and the sites remain valuable natural laboratories for eco-toxicological investigations on the biota residing therein (Bryan 1983; Bryan and Gibbs 1983; Cain et al. 2004). Silver (Ag) was one of the most important metals mined in the area; for example, outputs of more than 17 tons of $\mathrm{Ag}$ are recorded between 1853 and 1884 from the West Looe River, that flows into the Looe estuary, south-east Cornwall (Dewey 1921). Ag has had a long history of human usage, including as jewellery and in medicine, dentistry and now, most significantly, in electronics due its thermal and electrical conductivity properties (Luoma 2008). It is also regarded as a highly toxic metal with the main sources of contamination to the marine environment being derived from wastewater effluents and acid mine drainage (Tappin et al. 2010). Yet, despite the toxic nature of $\mathrm{Ag}$ to marine animals (Ratte 1999), there are relatively few empirical studies reporting on the accumulation and effects in seaweeds.

Here, we investigate the effects of Ag, under two salinity regimes, on the growth, photosynthetic performance and production of and damage by ROS in Fucus ceranoides, an intertidal brown seaweed able to withstand the full range of salinities encountered in estuaries (Barreiro et al. 2002; Varma et al. 2013). We also report current levels of Ag pollution within the Looe estuary by analysing concentrations in sediment and two fucoid species (Fucus vesiculosus and $F$. ceranoides), and compare these to those recorded by Bryan and Hummerstone (1977) by sampling the exact same sites.

\section{Materials and methods}

\section{Sample collection and processing for silver analyses}

Three replicate surficial oxic sediment samples were collected from the same 11 locations of the West and East Looe Rivers and Looe estuary described in Bryan and Hummerstone (1977) (Fig. 1), using a polyethylene spatula and transferred to polypropylene centrifuge tubes. In the laboratory, each sample was sieved through $180 \mu \mathrm{m}$ Nylon mesh and the fine fraction, collected in a $250 \mathrm{ml}$ acid cleaned Pyrex beaker, was then vacuum-filtered through a $0.45 \mu \mathrm{m}$ Whatman membrane filter to remove excess water before being freeze-dried for $48 \mathrm{~h}$ in a clean polypropylene centrifuge tube (Varma et al. 2011).

Five whole individuals of $F$. vesiculosus or F. ceranoides (i.e. where $F$. vesiculosus was not present) ranging in length between 24 and $56 \mathrm{~cm}$ were collected concurrently during low tide, at just above the mid-intertidal zone, and transported to the laboratory in zip-locked polythene bags within cool boxes. In the laboratory, visible epiphytes and organic debris were removed from the seaweeds by washing in filtered seawater $(5$ and $0.8 \mu \mathrm{m})$ available on tap and excess water then removed by blotting with absorbent paper. All algal samples were freeze-dried, in clean zip-locked polythene bags, for $48 \mathrm{~h}$, then weighed and stored in desiccators to await digestion.

Freeze-dried sediment samples $(100 \mathrm{mg})$ and certified reference material (harbour sediment; BSI-LGC6156) were weighed in triplicate into Teflon digestion vessels of $4 \mathrm{ml}$ capacity, to which $4 \mathrm{ml}$ nitric acid and $1 \mathrm{ml}$ hydrochloric acid (both BDH, AnalaR) were added. Likewise, freezedried algal samples (70-100 mg) and certified reference material (Fucus spp.; IAEA-140) were placed in Teflon vessels containing $2.5 \mathrm{ml}$ of concentrated nitric acid. The tightly capped contents were then digested in a CEM-MDS 2000 microwave digester for 40 (sediment) or 45 (algae) min. After cooling, sediment, which were first filtered (Whatman, hardened- ashless paper $11.0 \mathrm{~cm}$ ), and algal digests were washed into $10 \mathrm{ml}$ volumetric flasks, made up to the mark with Milli-Q water and then transferred to $15 \mathrm{ml}$ polypropylene universal containers.

\section{ICP-MS analyses}

Sediment and algal digests were analysed for silver (Ag107) by inductively coupled plasma mass spectrometry (ICP-MS; using a Thermo X Series II quadrupole-based benchtop instrument (Thermo Scientific, Hemel Hempstead, UK) with a concentric glass nebuliser, conical spray chamber and impact bead. Coolant, auxiliary and nebuliser gas flows were $13,0.86$ and $0.7 \mathrm{~L} \mathrm{~min}{ }^{-1}$, respectively; dwell time was $10 \mathrm{~ms}$, number of sweeps 50 and number of replicates 3. The instrument was calibrated using $\mathrm{Ag}$ standards, prepared as above, and internal standardisation was achieved by the addition of $10 \mu \mathrm{g} \mathrm{L}^{-1}$ of ${ }^{115} \mathrm{In}$ and ${ }^{193}$ Ir to all samples and standards (Varma et al. 2011, 2013).

\section{Sample collection for silver toxicity experiments}

The estuary catchment of the River Yealm is largely agricultural and has no recognized source of metallic contamination in contrast to other estuaries in south-west 
Fig. 1 Looe estuary showing the sampling areas used in Bryan and Hummerstone (1977) and the present study. Figure produced using Google Maps (2014) and Adobe Photoshop CC 2014

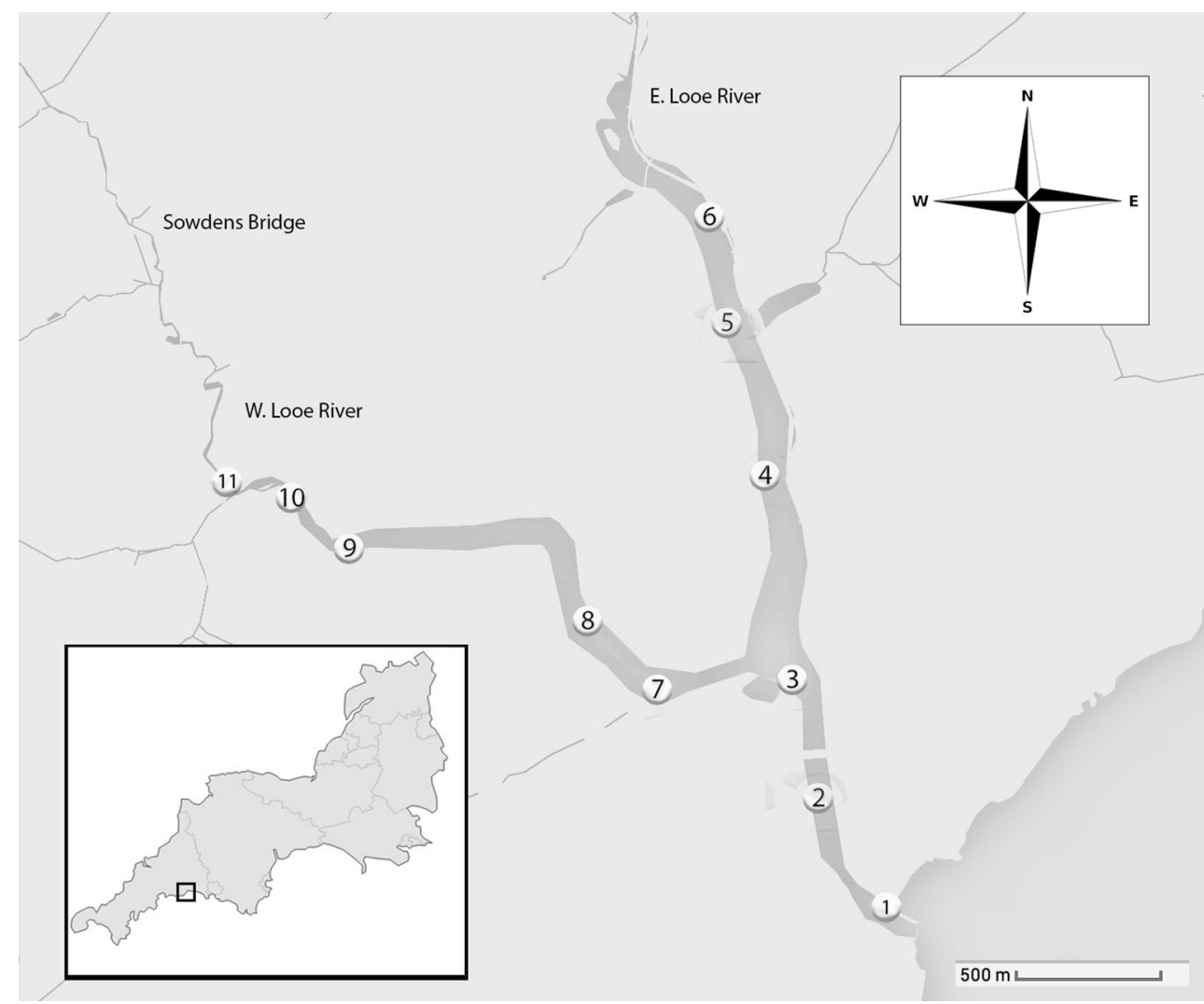

England (Langston et al. 2003). Thirty whole individuals $(15-20 \mathrm{~cm}$ in length) of $F$. ceranoides were hand-picked during low tide, on 31 May 2011 from the mid-intertidal rocky shore between Noss Mayo and Newton Ferrers, on the River Yealm $\left(50^{\circ} 18^{\prime} 51.59^{\prime \prime} \mathrm{N}, 4^{\circ} 1^{\prime} 53.60^{\prime \prime} \mathrm{W}\right)$ and transported in plastic containers to the laboratory. Algal samples were processed as above to remove epiphytes and debris, transferred to $2 \mathrm{~L}$ plastic aquaria tanks containing continuously aerated filtered $(0.22 \mu \mathrm{m})$ seawater and maintained under controlled environmental conditions of $15{ }^{\circ} \mathrm{C}$ and $240 \mu \mathrm{mol} \mathrm{m}{ }^{-2} \mathrm{~s}^{-1}$ of PAR (supplied by daylight fluorescent tubes) on a 12:12 h light/dark cycle for 5 days, prior to experimentation.

\section{Experimental protocols}

The chemically defined artificial seawater medium (ASM), Aquil was prepared at two salinities (10 and 28 psu), according to Morel et al. (1979) and Price et al. (1989); the $\mathrm{pH}$ of the two experimental salinities was 7.6 and 7.7, respectively. Using Aquil permitted the speciation of $\mathrm{Ag}$ in the two salinity regimes to be modelled (see below). A silver nitrate stock solution was prepared by dissolving silver nitrate (Fisher Scientific High Grade) salt in Milli-Q water to a concentration of $50 \mathrm{mg} \mathrm{L}^{-1}$.

Following the period of acclimation, the algae were briefly rinsed in Milli-Q water to remove adhering salts and then split between tanks containing high strength or diluted ASM and acclimated for a further $36 \mathrm{~h}$ before the addition of $\mathrm{Ag}$. Then, individual seaweeds were allocated, randomly, to aquaria tanks containing ASM of either 10 or 28 psu, and to which one of four nominal Ag solutions $(0,50$, $100,150 \mu \mathrm{g} \mathrm{L}^{-1}$ ) were added. There were three replicates per concentration for both salinities. The experiment was carried out under the culture conditions described above for a period of 14 days.

\section{Silver speciation}

The inorganic equilibrium speciation of $\mathrm{Ag}$ under the experimental conditions was calculated using the Windermere Humic Aqueous Model (WHAM, v6; Tipping 1998) and the stability constants in its default database. The chemical composition of ASM and Milli-Q water dilutions thereof was used to define the ionic composition of the samples. Temperature was set at $288 \mathrm{~K}, \mathrm{pH}$ at 7.7 and equilibrium with the atmosphere was assumed $\left(p \mathrm{CO}_{2}-\right.$ $\left.3.5 \times 10^{4} \mathrm{~atm}\right)$. The Davies equation was employed to calculate ion activity coefficients.

\section{Measured endpoints}

Relative growth rates (RGR) were measured from changes in wet biomass according to the formula: 
$\operatorname{RGR}(\%)=\left[\left(\operatorname{lnW}_{2}-\ln \mathrm{W}_{1}\right) \div\left(\mathrm{t}_{2}-\mathrm{t}_{1}\right)\right] \times 100$, where $\mathrm{W}$ is wet biomass at the beginning $\left(\mathrm{t}_{1}\right)$ and end $\left(\mathrm{t}_{2}\right)$ of the experimental period. Chlorophyll $a$ fluorescence was measured using a Photosynthetic Efficiency Analyser (Hansatech Ltd, England) Samples were initially dark adapted for $30 \mathrm{~min}$ prior readings being taken. $F_{\mathrm{m}}$, the maximum fluorescence yield of dark-adapted samples and $F_{0}$, the initial fluorescence yield, were recorded. The maximum quantum yield of PSII in the dark-adapted state is expressed as the ratio of variable to maximal chlorophyll a fluorescence $(F \mathrm{v} / F \mathrm{~m})$ which is derived from $\left(F_{\mathrm{m}}-F_{0}\right) /$ $F_{\mathrm{m}}$. Chlorophyll $a$ fluorescence analysis is a non-invasive technique that provides valuable information on the physiological status of plants and algae (Maxwell and Johnson 2000). Readings were taken for each replicate sample prior to the start of the experiment at the end of the exposure period. Fluorescence was initiated by a $1 \mathrm{~s}$ redlight pulse with a peak wavelength of $650 \mathrm{~nm}$ and an intensity of $3500 \mu \mathrm{mol} \mathrm{m}{ }^{-2} \mathrm{~s}^{-1}$. Saturating irradiance was provided by six high-intensity light-emitting diodes (LEDs, Hansatech Instruments) that were focused onto the algal surface to deliver even illumination.

Concentrations of hydrogen peroxide $\left(\mathrm{H}_{2} \mathrm{O}_{2}\right)$ were determined spectrophotometrically, according to Maharana et al. (2010). Algal samples $(0.5 \mathrm{~g}$ wet weight) were homogenized with $5 \mathrm{ml}$ of $10 \%(\mathrm{w} / \mathrm{v})$ TCA, centrifuged at $7000 \times g$ for $10 \mathrm{~min}$ and then $1 \mathrm{ml}$ of $1 \mathrm{M}$ potassium iodide and $1.5 \mathrm{ml}$ of $50 \mathrm{mM}$ potassium phosphate buffer ( $\mathrm{pH} 7.0$ ) was added to $0.5 \mathrm{ml}$ of the supernatant. Absorbance was measured at a wavelength of $390 \mathrm{~nm}, \mathrm{H}_{2} \mathrm{O}_{2}$ was the standard and the extinction coefficient was $43.6 \mathrm{M}^{-1} \mathrm{~cm}^{-1}$. Concentrations are expressed as mmol $\mathrm{H}_{2} \mathrm{O}_{2} \mathrm{~g}^{-1}$ wet biomass ( $\mathrm{Ye}$ et al. 2005). Levels of lipid peroxidation were determined from measuring the concentrations of malondialdehyde (MDA) in the seaweeds. MDA is a product of lipid peroxidation which reacts with thiobarbituric acid (TBA) to form an adduct known as TBA reactive substances (TBARS). TBARS measurements were performed according to Maharana et al. (2010). Algal samples ( $0.5 \mathrm{~g}$ wet biomass) were homogenized with $5 \mathrm{ml}$ of $10 \%(\mathrm{w} / \mathrm{v})$ trichloroacetic acid (TCA) and then centrifuged at $7000 \times g$ for $10 \mathrm{~min}$ using a microfuge. Two $\mathrm{ml}$ of $0.5 \%$ TBA solution was added to $1 \mathrm{ml}$ of the supernatant, the mixture incubated at $95{ }^{\circ} \mathrm{C}$ for $45 \mathrm{~min}$ and then cooled to room temperature followed by centrifugation at $4000 \times g$ for $10 \mathrm{~min}$. Absorbance was measured at a wavelength of $532 \mathrm{~nm}$ and 1,1,3,3, tetramethoxypropane, which breaks down to malondialdehyde (MDA) under the assay conditions, was used as the standard. Levels are expressed as nmol TBARS $\mathrm{g}^{-1}$ wet biomass.

\section{Data analyses}

The statistical software SPSS (version 21) was used for statistical analyses. Two way ANOVA tests were performed to test for differences in the concentrations of $\mathrm{Ag}$ recorded in the sediment $(\mathrm{n}=3)$ and Fucus $(\mathrm{n}=15)$ in between the different sampling sites in Looe estuary. The Spearman rank correlation coefficients were used to investigate the relationships between $\mathrm{Ag}$ in sediment/total $\mathrm{Ag}$ accumulated by the seaweeds. In addition, differences in the parameters $(n=3)$ between Ag treatments under the two salinity regimes were also tested. Differences between means were considered significant when $p<0.05$.

\section{Results}

\section{Silver pollution in the Looe estuary}

The mean $\mathrm{Ag}$ concentrations in sediment and algae collected from 11 different sites in the West Looe River, East Looe River and the Looe estuary are presented in Table 1. Fucus ceranoides was present only at sites 9,10 and 11 and is indicative of its ability to thrive under reduced salinity (Khfaji and Norton 1979). Average silver levels in the sediment were highest at sampling sites 9 and 11, both situated in the West River, and lowest at sampling site 1, situated at the estuary mouth. There was a general trend of increasing Ag concentrations with increasing distance from the mouth of the estuary. The highest level of accumulation by $F$. vesiculosus was at sites 4 and 5 in the East River, and

Table 1 Mean ( \pm standard deviation) concentrations $\left(\mathrm{mg} \mathrm{kg}^{-1}\right)$ of silver recorded in sediment and Fucus spp. (F. vesiculosus and $F$. ceranoides) sampled from 11 locations in the catchment of the Looe Estuary, south-west England

\begin{tabular}{lll}
\hline Sampling site & Sediment & Algae $_{\text {total }}$ \\
\hline $1(\mathrm{M})$ & $0.07 \pm 0.01$ & $0.27 \pm 0.09$ \\
$2(\mathrm{M})$ & $0.19 \pm 0.03$ & $0.66 \pm 1.01$ \\
$3(\mathrm{M})$ & $0.36 \pm 0.04$ & $0.32 \pm 0.10$ \\
$4(\mathrm{E})$ & $0.42 \pm 0.03$ & $1.19 \pm 0.50$ \\
$5(\mathrm{E})$ & $0.48 \pm 0.07$ & $1.28 \pm 0.50$ \\
$6(\mathrm{E})$ & $0.52 \pm 0.04$ & $0.51 \pm 0.32$ \\
$7(\mathrm{~W})$ & $0.50 \pm 0.09$ & $0.40 \pm 0.16$ \\
$8(\mathrm{~W})$ & $0.28 \pm 0.08$ & $0.63 \pm 0.49$ \\
$9(\mathrm{~W})$ & $1.16 \pm 0.21$ & $0.82 \pm 0.77$ \\
$10(\mathrm{~W})$ & $0.68 \pm 0.06$ & $0.43 \pm 0.96$ \\
$11(\mathrm{~W})$ & $1.23 \pm 0.36$ & $0.33 \pm 0.42$ \\
\hline
\end{tabular}

Refer to Fig. 1 for locations of the sampling sites ( $M$ estuary mouth, $E$ East Looe river, $W$ West Looe river)

Asterisk denotes the sites where Fucus ceranoides was collected 
by $F$. ceranoides at site 9 in the West River. There was no significant relationship between $\mathrm{Ag}$ levels in sediment and total concentrations in the seaweed.

\section{Toxic effects}

Growth rates of $F$. ceranoides were found to be significantly higher $(p<0.001)$ in the lower salinity treatment (10 psu), under control conditions (Fig. 2). Differences in growth rates were highly significant between both salinities for each concentration of $\mathrm{Ag}$ and within each salinity for all concentrations of $\mathrm{Ag}(p<0.001)$. There was also a significant interaction between salinity and Ag concentration. Growth of $F$. ceranoides was significantly affected by increasing concentrations of $\mathrm{Ag}$ under both salinity regimes (Fig. 2). Growth decreased significantly with increasing concentrations of $\mathrm{Ag}$ under both salinity regimes but the decline occurred at a lower concentration at the lower salinity treatment (Fig. 2). At $150 \mu \mathrm{g} / \mathrm{L}$, decline in growth was greater under 10 psu than 28 psu.

After the 14 days exposure to $\mathrm{Ag}$, there was no evidence for a significant decrease in the photosynthetic efficiency of F. ceranoides (Fig. 3). Initial mean values of $F_{v} / F_{m}$ were 0.73 and these were maintained under both salinity regimes and all Ag concentrations.

\section{Hydrogen peroxide content}

Differences in $\mathrm{H}_{2} \mathrm{O}_{2}$ concentrations were highly significant between both salinities for each concentration of silver and within in each salinity for all concentrations of silver $(p<0.001$; Fig. 4). The interaction between both salinities

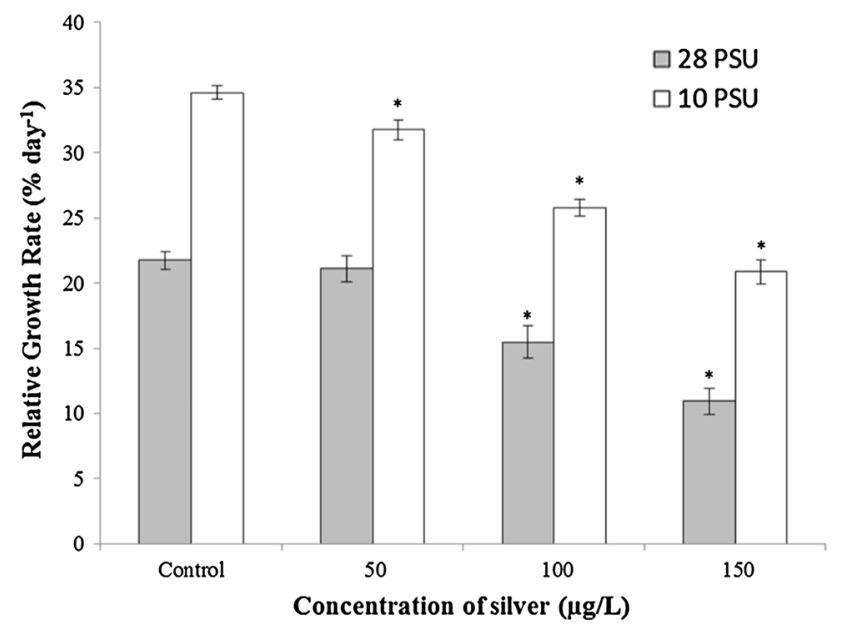

Fig. 2 The effects of $\mathrm{Ag}$ on the relative growth rate $\left(\%\right.$ day $\left.^{-1}\right)$ of Fucus ceranoides following 14 day exposure under two salinity regimes $(10,28 \mathrm{psu})$. Error bars indicate \pm standard deviation $(\mathrm{n}=3)$. Asterisks indicate treatments that are significantly different from controls $(p<0.05)$

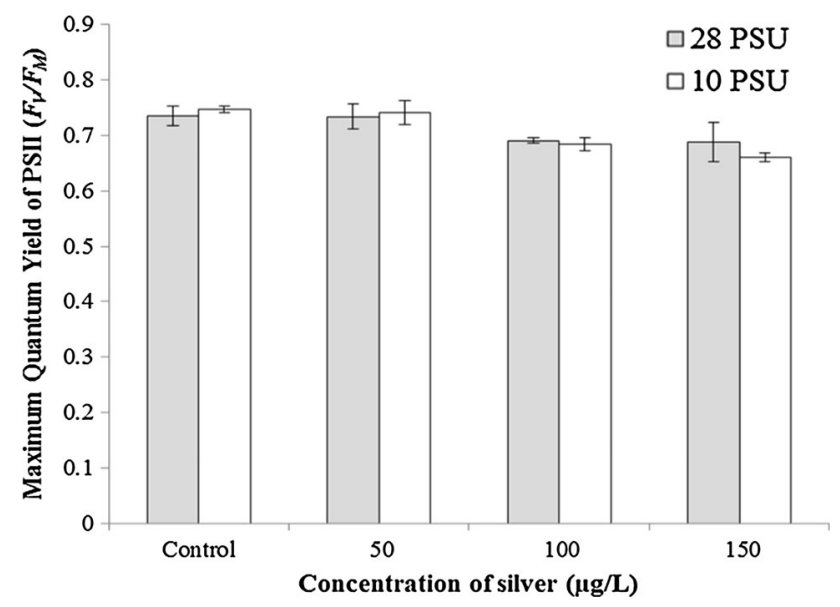

Fig. 3 Efficiency of photochemical energy conversion $\left(F_{\sqrt{ }} / F_{m}\right)$ of Fucus ceranoides following 14 day exposure to $\mathrm{Ag}$ under two salinity regimes $(10,28 \mathrm{psu})$. Error bars indicate \pm standard deviation $(\mathrm{n}=3)$

was also tested to be highly significant for $\mathrm{H}_{2} \mathrm{O}_{2}$ content $(p<0.001) . \mathrm{H}_{2} \mathrm{O}_{2}$ showed a pattern of increasing content with increasing concentrations of $\mathrm{Ag}$ at $10 \mathrm{psu}$. In contrast, at $28 \mathrm{psu}$, there was a small, but significant $(p<0.001)$ decrease in $\mathrm{H}_{2} \mathrm{O}_{2}$ content at 50 and $100 \mu \mathrm{g} / \mathrm{L}$ from control values. However, at this salinity, a large increase in $\mathrm{H}_{2} \mathrm{O}_{2}$ content was observed at the highest exposure concentration.

\section{Lipid peroxidation}

MDA concentrations are good indicators of lipid peroxidation. Under control conditions, lipid peroxidation was found to be similar at both salinities. Differences in MDA

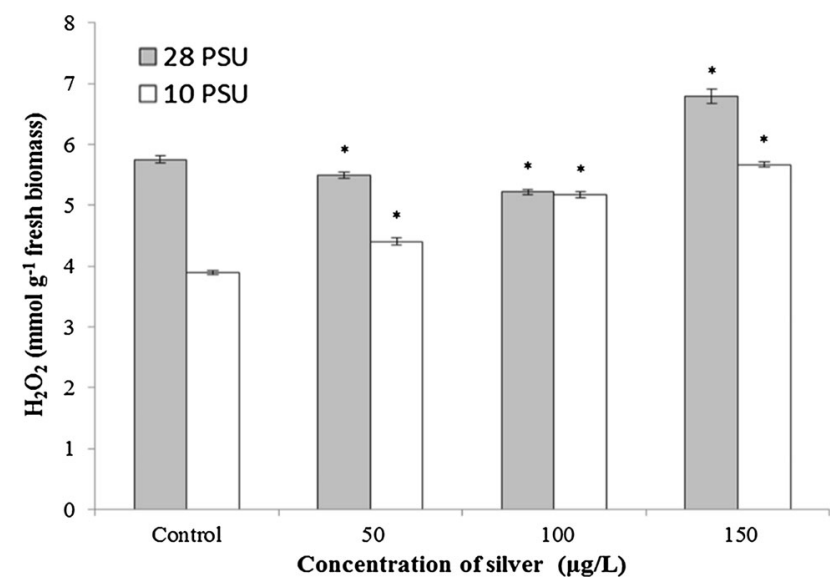

Fig. 4 Concentrations of hydrogen peroxide in Fucus ceranoides following 14 day exposure to $\mathrm{Ag}$ under two salinity regimes (10, 28 psu). Error bars indicate \pm standard deviation $(\mathrm{n}=3)$. Asterisks indicate treatments that are significantly different from the controls $(p<0.05)$ 
concentrations were highly significant between both salinities for each concentration of silver and within in each salinity for all concentrations of silver $(p<0.0001)$ (Fig. 5). The interaction between both salinities at $50 \mu \mathrm{g} / \mathrm{L}$ was also tested to be highly significant for MDA content $(p<0.001)$. At $10 \mathrm{psu}$, the levels of lipid peroxidation increased with increasing concentrations of Ag. At $28 \mathrm{psu}$, levels of lipid peroxidation observed were slightly lower at $100 \mu \mathrm{g} / \mathrm{L}$ in comparison to $50 \mu \mathrm{g} / \mathrm{L}$, but higher than under control conditions. At both salinities, highest lipid peroxidation occurred at the highest concentration of $\mathrm{Ag}$ $(150 \mu \mathrm{g} / \mathrm{L})$, over twofold higher than control levels.

\section{Silver speciation}

The inorganic speciation of aqueous silver under the experimental conditions is presented in Table 2. Charged chloro-complexes $\left(\mathrm{AgCl}_{2}{ }^{-}, \mathrm{AgCl}_{3}{ }^{2-}, \mathrm{AgCl}_{4}{ }^{3-}\right)$ were calculated to be the most abundant forms of inorganic $\mathrm{Ag}$ present, accounting for 96 and $99 \%$ of total aqueous $\mathrm{Ag}$ in the 10 and 28 psu salinity regimes, respectively. Neutral chloride and the free ion comprised $<1 \%$ and about $4 \%$ in the 28 and 10 psu media, respectively.

\section{Discussion}

Recently reported regional baseline concentrations ( $<33 \%$ percentile point of the dataset) for $\mathrm{Ag}$ in estuaries of south west England ranged between 0.07 and $0.18 \mathrm{mg} \mathrm{kg}^{-1}$ (Rainbow et al. 2011). The mean $\left(0.53 \mathrm{mg} \mathrm{kg}^{-1}\right)$ and range $\left(0.07-1.23 \mathrm{mg} \mathrm{kg}^{-1}\right)$ of silver concentrations in sediment of the Looe rivers and estuary recorded in this study are higher than these baseline levels but do not exceed the

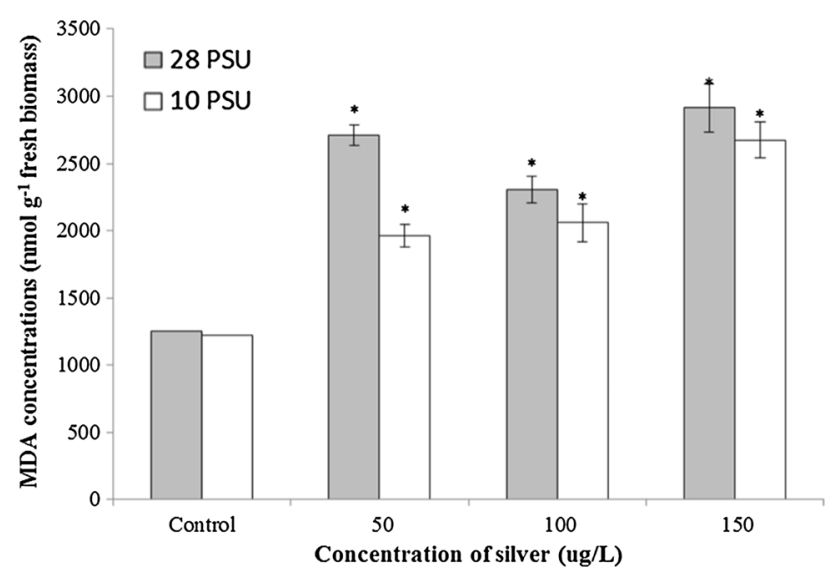

Fig. 5 Levels of lipid peroxidation (measured as MDA concentrations) in Fucus ceranoides following 14 day exposure to Ag under two salinities regimes $(10,28 \mathrm{psu})$. Error bars indicate \pm standard deviation $(\mathrm{n}=3)$. Asterisks indicate treatments that are significantly different from the controls $(p<0.05)$
$75 \%$ quartile (indicative of serious levels of contamination) which was the case in 2003 (Rainbow et al. 2011). A comparison of our results with those from the same sampling sites recorded in 1977 by Bryan and Hummerstone reveal that while the highest concentrations are to be found in the West Looe River, they are approximately $65 \%$ lower than they were 35 years ago. However, since there has been no routine sampling of these sites, information on possible annual variability is lacking.

The concentrations of Ag measured in the two Fucus spp. provide information on the bioavailability of dissolved $\mathrm{Ag}$ within the catchment. The highest mean concentrations were recorded in Fucus spp from the East Looe River and the lowest from the estuary mouth. The concentrations in $F$. ceranoides sampled at the limits of the tidal influence in the West Looe River were also higher than in F. vesiculosus form the estuary mouth. These results are consistent with the strong influence of salinity on the bioavailability of free Ag, due to its affinity for chloride ions (Luoma et al. 1995). Additionally, the bioavailability of other metals such as zinc and copper influence the accumulation of $\mathrm{Ag}$ (Ratte 1999). Hence, the accumulation of $\mathrm{Ag}$ by brown seaweeds in estuaries is the result of complex interactions with other metals and with salinity. Overall, the bioavailability of dissolved Ag has decreased by about $24 \%$ since 1977, but values remain similar to those recorded in 2006 by Rainbow et al. (2011).

The results obtained from the experimental study reflect this complexity and show that salinity modified Ag speciation and consequently its bioavailability and toxicity to the euryhaline brown seaweed $F$. ceranoides. Toxicity of dissolved $\mathrm{Ag}$ is usually attributed to the uptake and cellular effects of the free ionic silver $\left(\mathrm{Ag}^{+}\right)$and the moderately hydrophobic, neutral chloro-complex $\left(\mathrm{AgCl}^{0}\right)$ (Wood et al. 2010).The bioavailability of toxic $\mathrm{Ag}$ species $\left(\mathrm{Ag}^{+}\right.$and $\mathrm{AgCl}^{0}$ ) is almost six times higher at the lower salinity, $10 \mathrm{psu}$ in comparison to the higher salinity regime, $28 \mathrm{psu}$. Despite the less bioavailability of toxic Ag forms, growth is observed to decrease at higher concentrations of $\mathrm{Ag}$ under $28 \mathrm{psu}$, indicative of energy re-allocation towards reactive oxygen metabolism. Greater decreases in relative growth rates and higher increase in $\mathrm{H}_{2} \mathrm{O}_{2}$ content were observed at the lower salinity regime, whilst no significant changes were detected at $150 \mu \mathrm{g} / \mathrm{L}$ of $\mathrm{Ag}$ between the two salinity treatments, suggesting that the energy re-directed toward reactive oxygen metabolism is higher at the lower salinity, 10 psu. Growth was adversely affected by Ag under both salinity regimes but significant negative impacts were first observed at the lowest experimental concentration $(50 \mu \mathrm{g} /$ L) only in $10 \mathrm{psu}$ and the adverse effects of exposure to $150 \mu \mathrm{g} / \mathrm{L}$ were greater also under this salinity treatment. This may be explained by the higher bioavailability of the toxic $\mathrm{Ag}^{+}$at the $10 \mathrm{psu}$. The lowest growth rates recorded 
Table 2 The inorganic equilibrium speciation (\%) of $\mathrm{Ag}$ in Aquil of two salinities

\begin{tabular}{llll}
\hline Salinity & $\mathrm{Ag}^{+}$ & $\mathrm{AgCl}^{0}$ & Charged silver chloro-complexes $\left(\mathrm{AgCl}_{2}{ }^{-}, \mathrm{AgCl}_{3}{ }^{2-}, \mathrm{AgCl}_{4}{ }^{3-}\right)$ \\
\hline $10 \%$ & 0.04 & 3.59 & 96.37 \\
$28 \%$ & 0.01 & 0.61 & 99.38 \\
\hline
\end{tabular}

Speciation was calculated using the Windermere Humic Aqueous Model (WHAM, v6; Tipping 1998) in the experiment were at $28 \mathrm{psu}$. Moreover, under control conditions, $F$. ceranoides exhibited lower growth rates at 28 psu suggesting that the species' presence in low salinity environments may be due to an adaptive success under low salinity conditions.

In contrast to the growth results, no significant changes in maximum quantum yield of photosystem II were observed over the range of Ag concentrations used. However, previous studies have reported a decline in the yield of photosystem II following exposure for shorter periods of time. For example, in the freshwater microalga, Chlamydomonas reinhardtii have a reported a decline in the yield of photosystem II following a $5 \mathrm{~h}$ exposure to $53.5 \mu \mathrm{g} / \mathrm{L}$ Ag (e.g. Navarro et al. 2008) and Turner et al. (2012) reported a significant decline in the effective quantum yield of PSII $\left(F_{v} / F_{m}\right)$ in Ulva lactuca following $48 \mathrm{~h}$ exposure to $2.5 \mu \mathrm{g} / \mathrm{L} \mathrm{Ag}$. Therefore, it is possible that any transitory inhibition was compensated for by increasing the number of reaction centres as observed for other abiotic stressors in e.g. cyanobacteria (Vass et al. 2000). It is also possible that the parameter measured $\left(F_{v} / F_{m}\right)$, was not the most sensitive (see review by Ralph et al. 2007). For example, Zhang et al. (2014) observed that photosystem I (PSI) has a higher sensitivity to ROS and the sensitivity of PSII was lower in comparison to PSI in the leaves of cucumber.

The apparent uncoupling of growth from photosynthetic activity has been observed previously for other metals (e.g. Brown and Newman 2003; Han et al. 2008). It has been suggested this phenomenon could be related to the re-allocation of the energy captured by the light reactions of PSII and PS1 away from carbon assimilation and growth towards maintaining cell integrity, including offsetting the production of ROS. For example, Li and Brawley (2004) have reported that generation of antioxidants in Fucus species was energetically expensive and diverted metabolic resources away from growth and reproduction.

Compared with other metals, the relationship between $\mathrm{Ag}$ and reactive oxygen metabolism in macroalgae is very limited; however information is available for other photoautotrophs. For example, an empirical study on the freshwater alga, Chlamydomonas reinhardtii revealed that $\mathrm{Ag}$ was a strong inducer of ROS and this was due to the high affinity of $\mathrm{Ag}$ ions for thiol groups Szivak et al. (2009). Using Arabidopsis thaliana to investigate ROS generation by Ag in plants, Navabpour et al. (2003) observed the increased expression of senescence-enhanced genes such as the LC54 gene. By combining treatments with quenchers of ROS such as ascorbate, tiron and benzoic acid, they found the expression of the LC54 gene and other senescence-enhanced genes to be directly related to elevated levels of oxidative stress in the plant tissues. Thus, ROS generated due to Ag exposure could play a role in regulating cell death. Further studies are required to assess whether this type of mechanism can help explain the declining growth rates in $F$. ceranoides with increasing $\mathrm{Ag}$ concentrations.

Salinity, in the absence of Ag, also significantly affected relative growth rates of $F$. ceranoides, with values consistently lower at 28 psu. Growth is regarded to be a good measure of a plants ability to tolerate salt stress because growth requires maintenance of cell turgor (Hellebust 1976; Huang and Redmann 1995). Under reduced salinities that are encountered at the upper reaches of estuaries, $F$. ceranoides is able to out-compete other Fucus spp; for example, germlings of $F$. ceranoides can develop from zygotes under salinities down to 8.5 psu, whilst those of $F$. vesiculosus do not survive below 24 psu (Khfaji and Norton 1979). The higher concentrations of $\mathrm{H}_{2} \mathrm{O}_{2}$ and levels of lipid peroxidation at $28 \mathrm{psu}$ further indicate that salinity poses an additional stress for this alga. Cairrao et al. (2004) founds that in $F$. ceranoides collected from sites with higher salinity, in comparison to sites with low salinity, exhibited significantly higher concentrations of glutathione S-transferase (GST), an enzyme that plays an important role in the cellular detoxification of peroxidised lipids. Increased antioxidant activity at high salinities lends support to the hypothesis that metabolic resources are being reallocated towards reactive oxygen metabolism under 28 psu treatment. Thus the ability of $F$. ceranoides to outcompete $F$. vesiculosus at salinities below $17 \mathrm{psu}$ is reversed under full salinity which in part is due to negating the cellular effects of ROS.

The stress posed by higher salinity and exposure to $\mathrm{Ag}$, decreases the growth potential in $F$. ceranoides with energetic resources potentially being utilized to combat cellular stress. The results indicate that the levels of lipid peroxidation and $\mathrm{H}_{2} \mathrm{O}_{2}$ are higher at the higher salinity regime, 28 psu for each treatment of $\mathrm{Ag}$ whilst growth rates are also lower for each treatment of $\mathrm{Ag}$ at this salinity. This result suggests that although energy derived from photosynthesis is going towards countering the adverse effects of ROS production at $10 \mathrm{psu}, F$. ceranoides is able 
to allocate resources for the purpose of growth at low salinities. This consequently reduces a populations ability to respond to short-term favourable conditions and reducing its potential for success. Therefore studying algal growth rates can present a sensitive measurement of toxicity and also provide realistic insight to the actual inhibition within the system Suter and Lewis (1989).

The variability in concentrations of $\mathrm{H}_{2} \mathrm{O}_{2}$ and MDA at the 28 psu salinity regime may also be explained the additional stress faced by the alga at this salinity. The results indicate variable concentration of $\mathrm{H}_{2} \mathrm{O}_{2}$ at 28 psu, different to the clear pattern of increase with increasing concentrations of $\mathrm{Ag}$ at the $10 \mathrm{psu}$ salinity regime. Therefore, in ecotoxicological studies using euryhaline species, it is important to investigate the interaction with salinity as an additional environmental stressor. Salinity can be lowered by freshwater input from rivers to estuaries and algae such as $F$. ceranoides can be negatively affected by the higher abundance of $\mathrm{Ag}$ in its toxic and bioavailable $\left(\mathrm{Ag}^{+}, \mathrm{AgCl}^{0}\right)$ forms.

\section{Conclusions}

Concurrent analyses of Fucus spp and sediments indicate that while $\mathrm{Ag}$ concentrations remain high in some sections of Looe estuary, there has been a general decline over the past 35 years. Results from the experimental study indicate that $\mathrm{Ag}$ is toxic to the euryhaline species $F$. ceranoides as observed by a decrease in growth rates, increase in ROS and lipid peroxidation at both salinity regimes studied. Toxicity is influenced by salinity which alters the bioavailability of toxic Ag forms.

Acknowledgments We gratefully acknowledge technical support provided by Angela Harrop, Andrew Atfield and Andrew Fisher.

Conflict of interest The authors declare that they have no conflicts of interest.

\section{References}

Barreiro R, Picaldo L, Real C (2002) Biomonitoring heavy metals in estuaries: a field comparison of two brown algae species inhabiting upper estuarine reaches. Environ Monit Assess 75:121-134. doi:10.1023/A:1014479612811

Brown MT, Newman JE (2003) Physiological responses of Gracilariopsis longissima (S.G. Gmelin) Steentoft, L.M. Irvine and Farnham (Rhodophyceae) to sub-lethal copper concentrations. Aquat Toxicol 64:201-213. doi:10.1016/S0166-445X(03)00054-7

Bryan GW (1983) Brown seaweed, Fucus vesiculosus, and the gastropod, Littorina littorea, as indicators of trace-metal availability in estuaries. Sci Total Environ 28:91-104. doi:10.1016/ S0048-9697(83)80010-2
Bryan GW (1984) Pollution due to heavy metals and their compounds. In: Kinne O (ed) Marine ecology part 3. Wiley, London, pp 1289-1430

Bryan GW, Gibbs PE (1983) Heavy metals in the Fal Estuary, Cornwall: a study of long-term contamination by mining waste and its effects on estuarine organisms. Occas Publ Mar Biol Assoc UK 2:1-112

Bryan GW, Hummerstone LG (1977) Indicators of heavy metal contamination in the Looe Estuary (Cornwall) with particular regard to silver and lead. J Mar Biol Assoc UK 57:75-92. doi:10. 1017/S002531540002124X

Burzynski M, Zurek A (2007) Effects of copper and cadmium on photosynthesis in cucumber cotyledons. Photosynthetica 45:239-244. doi:10.1007/s11099-007-0038-9

Cain DJ, Luoma SN, Wallace WG (2004) Linking metal bioaccumulation of aquatic insects to their distribution patterns in a mining-impacted river. Environ Toxicol Chem 23:1463-1473. doi:10.1897/03-291

Cairrao E, Couderchet M, Soares AMVM, Guilhermino L (2004) Glutathione-S-transferase activity of Fucus spp. as a biomarker of environmental contamination. Aquat Toxicol 70:277-286. doi:10.1016/j.aquatox.2004.09.005

Collen J, Davison IR (1999) Reactive oxygen production and damage in intertidal Fucus Spp. (Phaeophyceae). J Phycol 35:54-61. doi:10.1046/j.1529-8817.1999.3510054.x

Dewey H (1921) Lead, silver-lead and zinc ores of Cornwall, Devon and Somerset. Economic Memoirs (Special Reports on Mineral Resources), Geological Survey of the United Kingdom 21, 72

Esposito A, Pagnanelli F, Lodi A, Soliso C, Veglio F (2001) Biosorption of heavy metals by Sphaerotilus natans: an equilibrium study at different $\mathrm{pH}$ and biomass concentrations. Hydrometallurgy 60:129-141. doi:10.1016/S0304-386X(00)00195-X

Halliwell B, Gutteridge JMC (1989) Free radicals in biology and medicine, 2nd edn. Clarendon Press, Oxford

Han T, Kang SH, Park JS, Lee HK, Brown MT (2008) Physiological responses of Ulva pertusa and $U$. armoricana to copper exposure. Aquat Toxicol 86:176-184. doi:10.1016/j.aquatox. 2007.10.016

Hellebust JA (1976) Osmoregulation. Annu Rev Plant Physiol 27:485-505

Huang J, Redmann RE (1995) Responses of growth, morphology, and anatomy to salinity and calcium supply in cultivated and wild barley. Can J Bot 73:1859-1866. doi:10.1139/b95-198

Khfaji AK, Norton TA (1979) The effects of salinity on the distribution of Fucus ceranoides. Estuar Coast Mar Sci 8:433-439. doi:10. 1016/0302-3524(79)90060-4

Langston WJ, Chesman BS, Burt GR, Hawkins SJ, Readman J, Worsfold P (2003) Characterisation of the South West European Marine Sites: Plymouth Sound and Estuaries cSAC, SPA. Marine Biological Association, Plymouth

Li R, Brawley SH (2004) Improved survival under heat stress in intertidal embryos (Fucus spp.) simultaneously exposed to hypersalinity and the effect of parental thermal history. Mar Biol 144:205-213. doi:10.1007/s00227-003-1190-9

Luoma SN (2008) Silver nanotechnologies and the environment: old problems or new challenges? Project on emerging nanotechnologies

Luoma SN, Ho YB, Bryan GW (1995) Fate, bioavailability and toxicity of silver in estuarine environments. Mar Pollut Bull 31:44-54. doi:10.1016/0025-326X(95)00081-W

Maharana D, Jena K, Pise NM, Jagtap TG (2010) Assessment of oxidative stress indices in a marine macro brown alga Padina tetrastromatica (Hauck) from comparable polluted coastal regions of the Arabian Sea, West coast of India. J Environ Sci 22:1413-1418. doi:10.1016/S1001-0742(09)60268-0 
Mamboya FA (2007) Heavy metal contamination and toxicity, studies of macroalgae from the Tanzanian Coast: 1-48. Stockholm University

Maxwell K, Johnson GN (2000) Chlorophyll fluorescence-a practical guide. J Exp Bot 51:659-668. doi:10.1093/jexbot/51.345. 659

Morel FMM, Reuter JG, Anderson DM, Guillard RRL (1979) Aquilchemically defined phytoplankton culture-medium for tracemetal studies. J Phycol 15:135-141. doi:10.1111/j.1529-8817. 1979.tb02976.x

Navabpour S, Morris K, Allen R, Harrison E, Mackerness SAH, Buchanan- Wollaston V (2003) Expression of senescence-enhanced genes in response to oxidative stress. J Exp Bot 54:2285-2292. doi:10.1093/jxb/erg267

Navarro E, Piccapietra F, Wagner B, Marconi F, Kaegi R, Odzak N, Sigg L, Behra R (2008) Toxicity of Silver Nanoparticles to Chlamydomonas reinhardtii. Environ Sci Technol 42:8959-8964. doi:10.1021/es801785m

Pinto E, Sigaud-Kutner TCS, Leitao MAS, Okamotmo OK, Morse D, Colepicolo P (2003) Heavy metal induces oxidative stress in algae. J Phycol 39:1008-1018. doi:10.1111/j.0022-3646.2003. 02-193.x

Price NM, Harrison GI, Hering JG, Hudson RJ, Nirel PMV, Palenik B, Morel FMM (1989) Preparation and chemistry of the artificial algal culture medium Aquil. Biol Oceanogr 6:443-461. doi:10. 1080/01965581

Rai LC, Gaur JP, Kumar HD (2008) Phycology and heavy metal pollution. Biol Rev 56:99-151. doi:10.1111/j.1469-185X.1981. tb00345.x

Rainbow PS, Kriefman S, Smith BD, Luoma SN (2011) Have the bioavailabilities of trace metals to a suite of biomonitors changed over three decades in SW England estuaries historically affected by mining. Sci Total Environ 409:1589-1602. doi:10.1016/j. scitotenv.2011.01.012

Ralph PJ, Smith RA, Macinnis-Ng CMO, Seery CR (2007) Use of fluorescence-based ecotoxicological bioassays in monitoring toxicants and pollution in aquatic systems: review. Toxicol Environ Chem 89:589-607. doi:10.1080/02772240701561593

Ratte HT (1999) Bioaccumulation and toxicity of silver compounds: a review. Environ Toxicol Chem 18:89-108. doi:10.1002/etc. 5620180112

Salgado LT, Andrade LR, Amado-Filho GM (2005) Localization of specific monosaccharide in cells of the brown alga Padina gymnospora and the relation to heavy-metal accumulation. Protoplasma 225:123-128. doi:10.1007/s00709-004-0066-2
Suter GW, Lewis MA (1989) Silver transport and impact in estuarine and marine systems. In: Aquatic toxicology and environmental fate, vol 11, pp 5-18. ASTM STP 1007, Philadelphia

Szivak I, Behra R, Sigg L (2009) Metal induced reactive oxygen species production in Chlamydomonas reinhardtii (Chlorophyceae). J Phycol 45:427-435. doi:10.1111/j.1529-8817.2009.00663.x

Tappin AD, Barriada JL, Braungardt CB, Evans EH, Patey MD, Achterberg EP (2010) Dissolved silver in European estuarine and coastal waters. Water Res 44:4204-4216. doi:10.1016/j. watres.2010.05.022

Tipping E (1998) Humic ion-binding model VI: an improved description of the interactions of protons and metal ions with humic substances. Aquat Geochem 4:3-47. doi:10.1023/a:1009627214459

Turner A, Brice D, Brown MT (2012) Interactions of silver nanoparticles with the marine macroalga, Ulva lactuca. Ecotoxicology 21:148-154. doi:10.1007/s10646-011-0774-2

Varma R, Turner A, Brown MT (2011) Bioaccumulation of metals by Fucus ceranoides in estuaries of South West England. Mar Pollut Bull 62:2557-2562. doi:10.1016/j.marpolbul.2011.08.016

Varma R, Turner A, Brown MT, Millward GE (2013) Metal accumulation kinetics by the estuarine macroalga, Fucus ceranoides. Estuar Coast Shelf Sci 128:33-40. doi:10.1016/j. ecss.2013.05.014

Vass I, Kirilovsky D, Perewoska I, Máté Z, Nagy F, Etienne AL (2000) UV-B radiation induced exchange of the D1 reaction centre subunits produced from the psbA2 and psbA3 genes in the Cyanobacterium synechocystis sp. PCC 6803. Eur J Biochem 167:2640-2648. doi:10.1046/j.1432-1327.2000.01274.x

Wood CM, Grosell M, McDonald MD, Playle RC, Walsh PJ (2010) 532 Effects of waterborne silver in a marine teleost, the gulf toadfish533 (Opsanus beta): effects of feeding and chronic exposure on bioaccumulation. Aquat Toxicol 99:138-148. doi:10.1016/j.aquatox.2010.04.012

Ye J, Li Y, Teruya K, Katakura Y, Ichikawa A, Eto H, Hosoi M, Nishimoto S, Shirahata S (2005) Enzyme-digested fucoidan extracts derived from seaweed Mozuku of Cladosiphon novaecaledoniae kylin inhibit invasion and angiogenesis of tumour cells. Cytotechnology 47:117-126. doi:10.1007/s10616-005-3761-8

Zhang ZS, Yang C, Gao HY, Zhang LT, Fan XL, Liu MJ (2014) The higher sensitivity of PSI to ROS results in lower chilling-light tolerance of photosystems in young leaves of cucumber. J Photochem Photobiol B 137:127-134. doi:10.1016/j.jphoto biol.2013.12.012 